\title{
Emerging Biomass Conversion Technologies for Obtaining Value-Added Chemicals and Fuels from Biomass
}

\author{
D K SHARMA* \\ Centre for Energy Studies, Indian Institute of Technology Delhi, New Delhi 110 016, India
}

(Received on 30 March 2014; Accepted on 02 August 2015)

\begin{abstract}
Biomass is a renewable fuel. Several technologies have been developed for biomass conversion to obtain value-added chemicals and fuels such as gasification, anaerobic digestion, hydrolysis, fermentation, and hydrogenation. Biomass may also be directly used for power generation. Interest in the production of bioethanol, biodiesel and biogas from the biomass has increased the world over. Efforts are also underway to make the production of hydrogen from the biomass cost effective. Availability of biomass is to be increased manifold. Improved scientific planning and management may help in growing plenty of biomass, which may be compressed and collected. Development of cost-competitive biomass conversion technologies such as chemical, thermochemical and biochemical conversion processes may afford the utilization of biomass to obtain hydrogen biogas, alcohols, biodiesel and other cleaner fuels for power generation and transport. Biomass may also afford the production of feedstock for chemical, petrochemical and other industries. This may help in establishing bioeconomy of the future.
\end{abstract}

Keywords: Biomass Conversion Technologies; Bioethanol; Biogas; Biodiesel; Biogasoline

\section{Introduction}

Manifold increase in oil prices, i.e. beyond US \$140/ barrel had compelled the world to think seriously about national energy securities. Oil reserves of the world may not last for more than 40-50 years at the present rate of consumption (Shafiee and Topal, 2009). Rate of consumption of oil is increasing with increase in world population and with increase in the standard of living of the masses. Coal reserves of the world are also limited and may not last for more than 100-150 years (Shafiee and Topal, 2009).

By 2050, world population may have doubled and thus fossil fuel consumption may also double. There is need to follow the trend which may afford an economic growth rate of $8-9 \%$ with perfect human resource management.

The world is undergoing a transition of moving to renewable energy sources which are cleaner and can be easily adopted in rural areas as well. Renewable energy sources such as solar photovoltaic, solar thermal, wind, geothermal, wave, mini-hydel energy, etc. generate power. However, these do not produce oil and natural gas which are required for transport, shipping, mining, etc. and also provide feedstock for fertilizer, dyes, and pharmaceuticals, chemical and petrochemical industries. In fact, bioenergy is the only renewable source of energy which can afford liquid as well as gaseous fuels, besides power. Fig. 1 shows a schematic representation of the current biomass conversion technologies for obtaining value-added fuels and chemicals.

\section{Need for Transition to Biofuels and Bio- sequestration}

The combustion of fossil fuels generates much $\mathrm{CO}_{2}$ - a greenhouse gas, responsible for global warming. There is an increasing thrust on biosequestration of

*Author for Correspondence: E-mail: sharmadk@ces.iitd.ac.in 


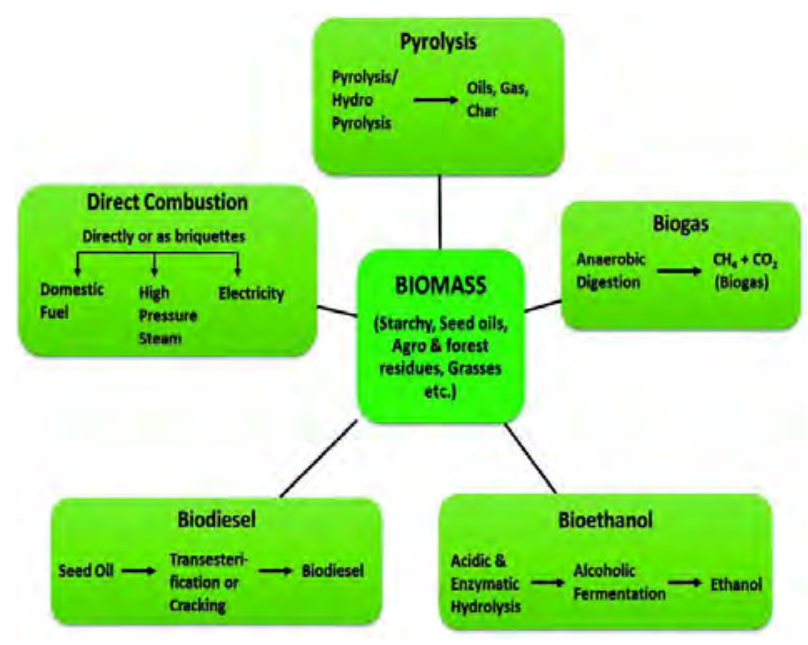

Fig. 1: Common methods of biomass utilization

$\mathrm{CO}_{2}$ by growing more trees to arrest the ill effects of global warming. Gupta and Demirbas (2010) reported that out of 6.49 billion tons of biomass available globally, only a small amount of approximately 2.48 million tons is in use. Almost all countries in the world are giving due importance to bioenergy and thus moving towards bioeconomy. However, one major challenge to the establishment of bioeconomy is that oil and coal are being utilized the world over at a scale of millions of tons per annum (http://www.bp.com/ content/dam/bp/pdf/Energy-economics/statisticalreview-2014/BP-statistical-review-of-world-energy2014-full-report.pdf) and therefore there may be a requirement for the production of biomass on a large scale to replace these. Thus, more biomass should be generated and made available for biomass conversion units. Sustainable energy production from agricultural waste and wastewater will help in decreasing our dependency on fossil fuels for our energy requirements (Angenent et al., 2004).

First generation biofuels include biogas production from cellulosic wastes (animal dung), ethanol from wheat or corn starch, sugarcane, beetroot, grapes, carbohydrates, etc., pyrolysis of biomass, direct combustion of biomass through fluidized bed combustion or improved stoves or through gasification, etc. Second generation biofuels such as biodiesel from lipids derived from oil seeds - palm, soybean, sunflower, castor, Jatropha curcas, Pongamia pinnata (non-edible seeds), etc. are already under the consideration of energy managers. The use of edible seed oils has led to the food versus fuel controversy. Therefore, in India there is a thrust to use non-edible seed oils as feedstock for biodiesel production. Research and development on third generation biofuels, i.e. production of biodiesel or biogasoline from microalgae has also started. Production of hydrogen and ethanol from microalgae and alcohol and biogas from macroalgae is also receiving attention.

\section{Bioenergy and Biosequestration of $\mathrm{CO}_{2}$}

Arresting unprecedented climate change, maintenance of global economic growth and substituting the role played by depleting oil are the major driving forces behind bioenergy development. There is need to reduce $25-40 \%$ of the $\mathrm{CO}_{2}$ emissions by 2020 and $80-90 \%$ of the $\mathrm{CO}_{2}$ emissions by 2050 to restrict global temperature rise by $2^{\circ} \mathrm{C}$ (as agreed by the 2009 Copenhagen Climate Change Summit, Stephens et al., 2010). Biomass production leads to utilization of $\mathrm{CO}_{2}$ through photosynthesis.

\section{Technological Options for Biomass Conversion}

There are three main routes which are available for biomass conversion to value-added chemicals, fuels, and other products (Goldstein, 1981; Wise, 1983).

1) Chemical Conversion Technologies

2) Thermochemical Conversion Technologies

3) Biochemical Conversion Technologies

Sharma and his researchers have extended research to the area of conventional and renewable energy sources and other areas in the last several years (Sharma, 2005a; Sharma, 2005b; Singh et al., 1984a; Biswas and Sharma, 2012; Biswas et al., 2013; Biswas and Sharma, 2013) Research has been conducted on the development of biomass conversion technologies in the past by several researchers (Gupta and Demirbas, 2010).

\section{Production of Biodiesel}

The world total biodiesel production was around 1.8 billion litres in 2003. In the EU, biodiesel is by far the 
biggest biofuel and represents $82 \%$ of the biofuel production (Demirbas and Balat, 2006). The EU production of biodiesel was 2.3 billion litres in 2006 (Demirbas, 2009a), Ma and Hanna (1999) concluded that biodiesel has become more attractive recently because of its environmental benefits and the fact that it is made from renewable resources. They also stated that challenges in biodiesel production lie in its cost and limited availability of fat and oil resources. Jatropha curcas (non-edible) seed oil is the main crop being proposed to be used for producing biodiesel in India. In order to improve the yield of oil from Jatropha curcas, research may be required in the area of genetic engineering to prepare suitable germ plasm, etc. (Discussion Meet DBT, 2007). However, Pongamia pinnata is also being considered as a potential oil seed species for the production of biodiesel (Fig. 2). For efficient production of biodiesel via transesterification, the following parameters will be important: the nature of feedstock, amount and type of alcohol and catalyst, operating temperature, and reaction time (Shahid \& Jamal, 2011). Glycerol may be utilized in cosmetic and other chemical industries. Cracking of Jatropha oil or any other seed oil seems to be another option other than trans-esterification (Biswas and Sharma, 2012, 2013; Biswas et al., 2013). Co-processing of biomass with other fuels has also been studied by the author and his research group (Biswas and Sharma, 2012, 2013; Biswas et al., 2013; Ahmaruzzaman and Sharma, 2005, 2007, 2008). The residual biomass may be used to obtain biogas and manure (Deeba et al., 2012) Algal species such as Chlorella vulgaris, Scenedesmus obliquus, Euglena gracilis, Spirulina plalensis, etc. can also be used for the production of biodiesel (Gautam et al., 2013). Botryococcus braunii contains hydrocarbons and lipids. It produces hydrocarbons ranging from $5-60 \%$ on dry weight basis. Culture conditions can be optimized for enhanced hydrocarbon production and research in this direction is underway (Sheehan et al., 1998). Algal lipids may also be subjected to cracking to obtain biogasoline and biodiesel.

Biodiesel is advantageous because it not only reduces greenhouse gas emissions but also helps to reduce a nation's reliance on crude oil imports.
Biodiesel industry provides support to agriculture industry by providing new labour and market opportunities for domestic crops. Even vehicle manufacturers have accepted that it enhances lubrication. Blends of biodiesel (up to 20\%) can be used in IC engines without many modifications (Demirbas, 2009b).

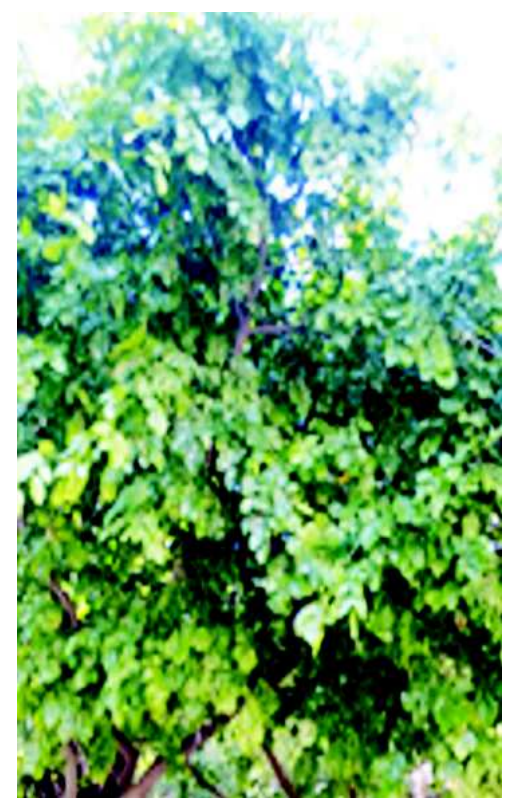

Fig. 2: Pongamia pinnata trees - oil producing plant used for biodiesel production

\section{Pyrolysis of Biomass - Thermochemical Conversion}

Agroresidues such as bagasse, wheat straw, jute sticks, rice straw, coconut shells, etc. can be subjected to pyrolysis either in retort reactors/fluidized bed pyrolyzers/fixed bed pyrolyzers or in drums. On pyrolysis, biomass may be converted into solid char, pyroligneous acid and tar and pyrolysis gas (Sharma et al., 1994a; Sharma and Prasad, 1986). Pyroligneous acid and tar may be used to produce value-added chemicals. Pyrolysis gas may be used as fuel (Ahmaruzzaman and Sharma, 2005, 2007b). However, further research and development in these areas may be required. These may also be co-cracked to obtain biogasoline and biodiesel as described earlier.

\section{Hydrolysis of Cellulose (Production of Ethanol)}

The world ethanol production has increased from 
around 16 billion litres a year in 1991 to 18.5 billion litres in 2001 (Demirbas, 2009a). In 2008, the global ethanol production was at 20.37 billion gallons per year. The United States become the world's leading ethanol producer and alone accounts for $43.8 \%$ of the global ethanol production, followed by Brazil (33.9\%), China (5\%) and India (3\%) (Demirbas, 2011). Novel alternative methods to produce biodiesel and other second generation fuels, from varied feed stocks, are hot topics of research, especially the ones involving synthetic biology. Along with this, focus is now being laid on improving cost effectiveness from encouraging large-scale use of alternative biofuels. Sharma and his research group have carried out research in the area of both acidic as well as enzymatic hydrolysis of lignocellulosic biomass (LCB) such as agroresidues to obtain bioethanol (Behera et al., 1996; Sharma et al., 1995a; Sharma and Das, 1992; Sharma et al., 1991; Singh et al., 1984a; Singh et al., 1984b; Singh et al., 1984c; Sharma and Sahgal, 1982; Sharma and Das, 1984; Sharma and Goldstein, 1990; Liu et al., 2012). Integrated processes to obtain value-added chemicals and fuels from hydrolysis of biomass were developed. Hemicellulose and cellulose can be hydrolysed by using acids to obtain fermentable sugars such as xylose, glucose, etc. These reducing sugars can be further fermented to obtain ethanol, butanol, etc. Recently, other substrates are also being considered for the production of bioethanol and valuable products, such as food wastes, weeds and grasses, etc. (Ganguly et al., 2012; Maitan-Alfenas et al., 2015; Ruan et al., 2013).

Cellulase enzyme may be used in the biochemical hydrolysis of cellulose. However, lignin inhibits the enzymatic hydrolysis of LCB. The delignification of LCB using alkali, steam, fungi or enzymes, helps in its enzymatic hydrolysis. Lignin obtained may be hydrocracked to yield aromatic chemicals and fuels. Of late, enzymatic hydrolysis of biomass is being preferred over acidic hydrolysis process (Lee et al., 1999; Aden et al., 2002; Zhang et al., 2007; Sun and Cheng, 2011; Maitan-Alfenas et al., 2015). However, further research and development is required to make the hydrolysis process cost effective and interest in this area has been revived.

\section{Liquefaction of Biomass}

Biomass can also be hydrogenated to obtain oil. Biomass can be hydrocracked at high temperature and pressure in the presence of catalyst to obtain liquid fuels which can be fractionated to yield a petroleumlike product. Fischer-Tropsch (FT) synthesis may also produce liquid fuels from $\mathrm{CO}, \mathrm{CO}_{2}$ and hydrogen by using iron oxide as a catalyst. Here, synthesis gas may be produced by the gasification of biomass. The author and his research group have reported the use of several effective catalysts for the same (Mohanty et al., 2011). Shift reaction may convert $\mathrm{CO}$ to $\mathrm{CO}_{2}$ and $\mathrm{H}_{2}$ after reaction with steam.

\section{Anaerobic Digestion of Biomass}

Lignocellulosic biomass, animal dung, night soil and lignocellulosic biomass containing proteinaceous lipids, fats or fatty acids can be subjected to anaerobic digestion to obtain biogas $\left(\mathrm{CO}_{2}+\mathrm{CH}_{4}\right)$. In India, MNRE, Government of India has also conducted extensive research along with several other organizations in this area. The author has also extended some research in this area (Sharma et al., 1995b; Sharma et al., 1994b; Sharma and Mbise, 1988).

There are two established digester designs.

\section{Floating Gas Holder Type}

\section{Fixed Dome Type}

The Biogas Programme of MNRE, Govt. of India is receiving due consideration in rural areas in India which not only leads to improved sanitation but could also provide digested slurry as good manure. Bottling of purified biogas i.e., after making it free from most of the $\mathrm{CO}_{2}$ (by scrubbing with water or alkali), has also been started for being supplied as a gaseous fuel similar to LPG or CNG. Biogas programme is also being extended in European countries such as Germany, UK, etc. and in several other nations in Asia such as China and Philippines.

\section{Biotransformations}

Enzymes can be obtained by using cheaper agro residues or forest residues by employing solid state 
fermentation (surface culture technique) or by liquid state fermentation (submerged culture technique). The enzymes thus produced may be used for hydrolysis, oxidation, reduction, esterification, elimination and substitution reactions, etc. (Sharma et al., 1995a). Ligninase enzyme may be used for biodegradation of lignins. White rot fungi may be used to produce ligninase or peroxidase enzymes (Behera et al., 1996; Sharma et al., 1997; Goldstein, 1981; Wise, 1983).

\section{Gasification of Biomass or Solid Wastes}

There is a good potential to utilize organic wastes to produce energy either through sanitary landfills or through direct incineration. Gasification refers to the conversion of biomass by partial oxidation to generate producer gas containing $\mathrm{CO}, \mathrm{H}_{2}, \mathrm{CH}_{4}, \mathrm{~N}_{2}, \mathrm{C}_{2} \mathrm{H}_{6}, \mathrm{NH}_{3}$, $\mathrm{CO}_{2}$, etc. If the gasification is carried out under pressure, then methane may also be obtained along with other gases. The use of catalyst such as $\mathrm{Na}_{2} \mathrm{CO}_{3} /$ $\mathrm{K}_{2} \mathrm{CO}_{3}$ helps in catalysing the gasification. Synthesis gas may be used in the Fischer-Tropsch synthesis for production of petroleum hydrocarbons (Mohanty et $a l ., 2011)$. Alternatively, this may be subjected to oxosynthesis for the production of alcohols.

Gas obtained can be used to generate power. Producer gas may also be used to produce hydrogen by shift reaction or alcohols by oxo-synthesis. This may also be used in the synthesis of methanol.

Two designs are used in the gasification of biomass.

1. Downdraft gasifier

2. Updraft gasifier

Since biomass contains more than $20 \%$ moisture, there is no need to supply steam from outside. Even gasification reactors used in the gasification of coal may be used for the gasification of biomass. Gasifiers may be used in the production of power using fuel cells also (Gaurav et al., 2010). Biomass particularly algae may also be used in the production of microbial fuel cells or by using hydrogen obtained from algae in the fuel cells (Balasundaram et al., 2007).

\section{Production of Hydrogen}

Hydrogen may be produced by the following routes:
1. Biophotolysis of water using green and blue green algae i.e., cyanobacteria.

2. Photobiological decomposition of organic compounds including organic wastes by photosynthetic bacteria.

3. Fermentation for hydrogen production from organic wastes.

Photosynthetic bacteria such as Rhodobacter sphaeriodes, $R$. capsulates, $R$. rubrum, etc. can be utilized in the production of hydrogen. These bacteria can even catalyse microbial shift reactions to convert $\mathrm{CO}$ and water to hydrogen and $\mathrm{CO}_{2}$. The author has extended some research on the production of hydrogen from Spirulina sp. by biological processing (Balasundaram et al., 2007).

Hydrolysate from the acidic or enzymatic hydrolysis of lignocellulosic biomass may be either fermented to obtain hydrogen or this may be subjected to steam reforming to generate hydrogen. Glycerol may also be subjected to steam reforming to produce $\mathrm{H}_{2}$. Hydrogen may also be obtained by steam reforming of glucose or glycerol at higher temperatures $\left(800^{\circ} \mathrm{C}\right)$ under atmospheric pressure in the presence of $\mathrm{Ni}$ as a catalyst. The use of Pt catalyst affords lower temperatures $\left(225-265^{\circ} \mathrm{C}\right)$ but requires higher pressures (27-54 bar) (Gupta and Demirbas, 2010). Electricity generated by solar energy, OTEC, wind or geothermal energy can also be used for the electrolysis of water to produce $\mathrm{H}_{2}$. Methane of biogas may be cracked by using solar heat at $2000 \mathrm{~K}$. Methane breaks down to $\mathrm{H}_{2}$ and nanocarbon materials. Steam reforming of ethanol can also generate $\mathrm{H}_{2}$. The $\mathrm{H}_{2}$ thus generated may be utilized in fuel cells to generate power.

\section{Energy from Organic Wastes}

There are different types of organic solid wastes e.g., rural, urban or municipal solid waste (MSW), industrial wastes and night soil and cellulosic wastes. Wastes can be subjected to incineration to generate power. However, organic wastes can also be utilized to obtain biogas and other products through digesters or landfills. Solid waste may also be disposed off in sanitary landfills and biogas can be generated, which can be 
used for power generation. Both incinerator and sanitary landfill practices are prevalent in India and elsewhere in the world.

\section{Other Methods of Efficient Utilization of Biomass}

Co-processing of biomass with plastics, petroleum coke, vacuum residue, lignite, coal, coke breeze, and rubber tyres can be practised to utilize biomass for easy transportation and storage, etc. Co-processing may involve co-firing, co-gasification/catalytic gasification or co-pyrolysis/co-cracking, etc.

1. Biomass along with plastics is used for densification of briquettes for enhancement of calorific value. However, special incinerators may be required depending upon the type of plastic being used/processed.

2. Briquetting of biomass can be done to produce compact fuel.

3. Value addition in the form of drugs (Sharma and Hall, 1991; Sharma et al., 1979; Parthasarathy et al., 1979), nanocomposites, speciality chemicals, smart materials, biomaterials, etc. is possible using land biomass.

The author has carried out some research where the production of drugs as natural products may be linked with the production of biofuels in the industries (Sharma and Hall, 1991; Sharma et al., 1979; Sharma, 2005a; Sharma, 2005b; Joseph et al., 2007; Joseph and Sharma, 2010; Ahmaruzzaman and Sharma, 2007b). Coprocessing/co-cracking of biomass-derived materials with waste plastics and other waste materials has also been carried out (Biswas and Sharma, 2012; Biswas et al., 2013; Ahmaruzzaman and Sharma, 2005, 2007b, 2008) to obtain biofuels i.e., biogasoline and biodiesel.

\section{Potential of Petrocrops}

There are certain plants which are laticiferous, contain essential oils or resinous such as Calotropis procera, Euphorbia lathyrus, Euphorbia tirucali, Euphorbia nerifolia, Simmondsia chinesis (Jojoba), pine, Lantana camara, Eucalyptus, etc. (Kalita, 2008) (Fig. 3). These plants yield terpenes

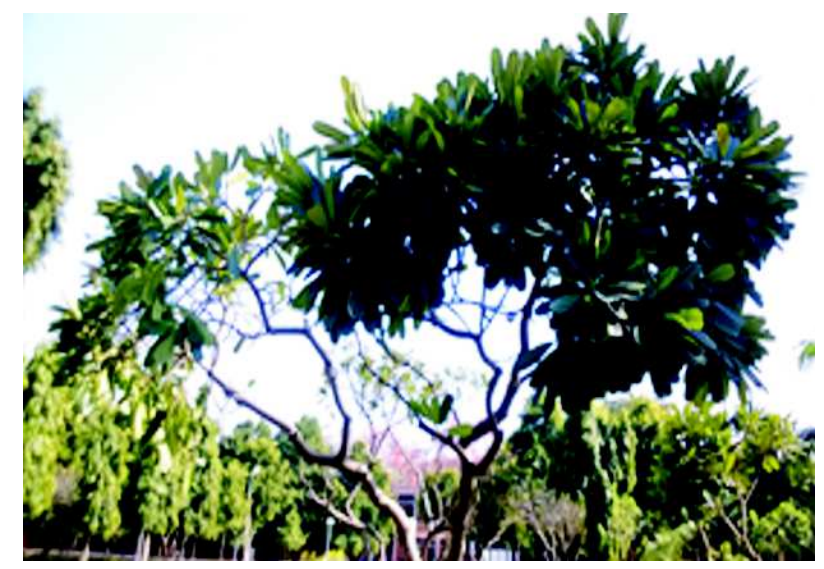

(A) Plumeria alba

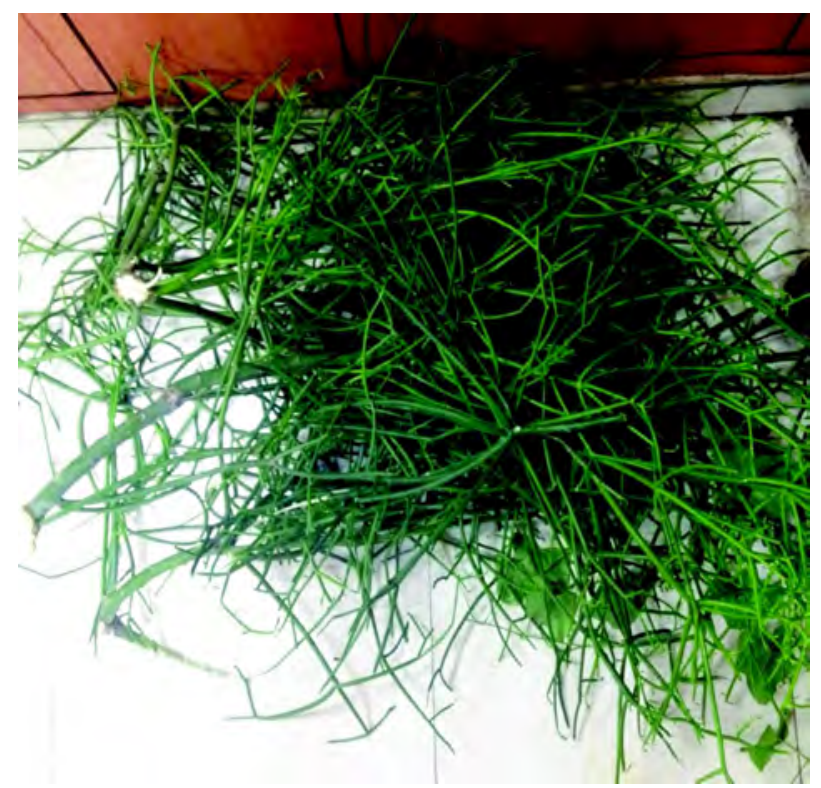

(B) Euphorbia tirucalli

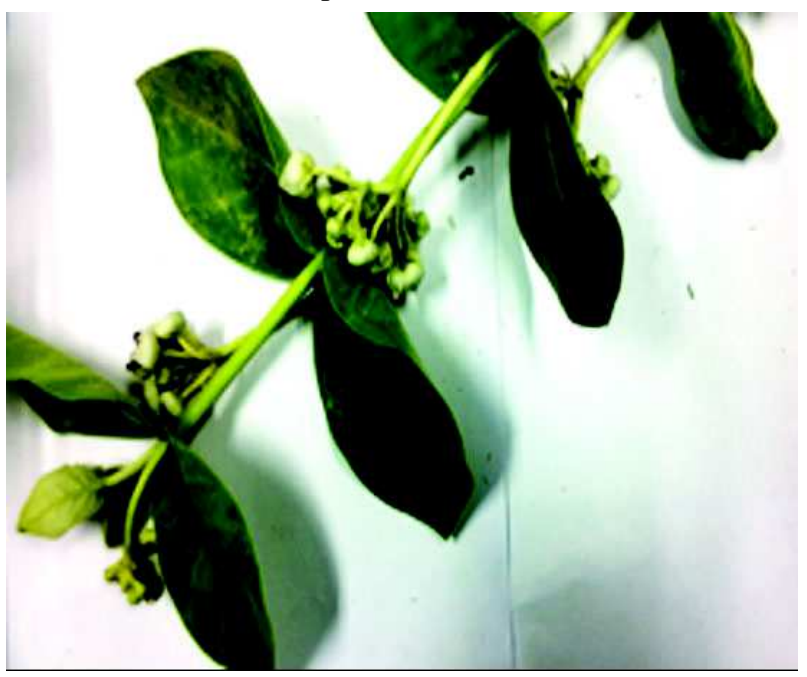

(C) Calotropis procera

Fig. 3: Some important petrocrops 
(biocrude) as extractives. Terpenes (biocrude) may be hydrocracked to yield hydrocarbons such as petroleum. Biodegradation of latex can also be studied (Sharma et al., 1996; Behera et al., 1995; Sharma and Sahgal, 1982). In fact, Pittosporum resiniferum, Copeifera multijuga, Copeifera landsdorfii, Plumeria rubra, Plumeria alba, etc. have been identified as potential candidates for petrofarming. The author has also recommended some candidates for petrofarming. Here, photosynthesis proceeds to the production of triterpenes, hydrocarbons, etc. Further research in this area is required to establish the economics of petrocrops and petrofarming. Fig. 3 shows some of the potential petrocrop species.

\section{Bioenergy from Algae}

The world has moved to the third generation of biofuels i.e. fuels from microalgae and macroalgae. Algae appeared on this earth millions of years ago and it moved from water to earth to get transformed to plants and trees later. Algae are responsible for almost 50\% of the oxygen generation on earth. Algae have the potential to yield lipids (and thus biodiesel or biogasoline), biohydrogen, bioethanol and biogas. These have been commercially exploited to obtain food, feed, vitamins, proteins, cosmetics, aminoacids, dyes, fatty acids, medicines, etc. through mostly open pond reactors. USDOE had earlier conducted extensive research on screening more than 3000 algal cultures for their potential to yield biodiesel i.e., lipids

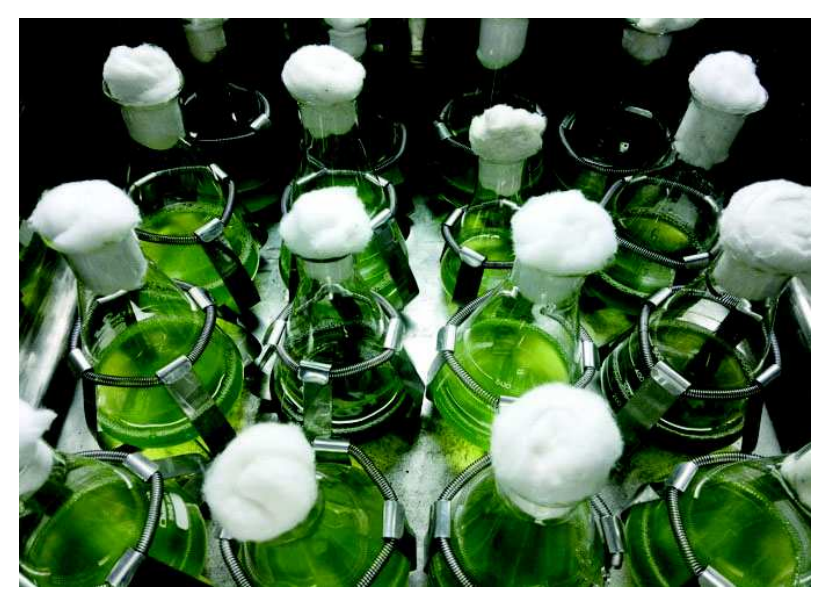

Fig. 4: Cultivation of algae in shake-flasks
(Sheehan et al., 1998). Research is being extended the world over on the production of value-added fuels and chemicals from algae. Algal bioreactors are being developed to yield enhanced amounts of lipids. There is a need to extend research and development on the production of biofuels from microalgae and macroalgae. This may also involve oceanographic management as it may require the managing of the macroalgae farms or forests which may also help in the biosequestration of $\mathrm{CO}_{2}$.

\section{Production of Biomass at Huge Scales}

A major challenge would be to enhance the production of biomass on nonagricultural land at scales matching that of fossil fuels. This would be required to establish bioeconomy. A major problem in the biomass-based industries is the cost of collection, transport, storage, moisture contents, lower calorific value and crushing of biomass (a fibrous material). The cost of collection and transportation can be considerably reduced by preconditioning, i.e. solar drying and compacting and appropriately locating the intermediate centres where the loose biomass can be compacted, stored and used in the conversion facility. However, further research may be required to grow more aquatic as well as land biomass through improved horticulture or other botanical and agricultural practices by utilizing the land which is not being exploited for food crops.

The use of tractors, trolley trailers and tractor wagons up to a short distance and of tractors and trawlers for long distances may be recommended. Transport of briquettes by trucks may be economical at all distances. However a better management of transportation of biomass may be planned depending upon the availability of biomass in a particular region.

The availability of biomass may be increased by the upgradation of degraded soil/land, by using arid or semi-arid land. Even algal ponds may be set up in abandoned mines or on rooftops for growing more biomass.

After the depletion of fossil fuels, biomass may be the only dependable source of fuels and chemical feedstock. Therefore, there is a need to grow more 
biomass as land and aquatic crops. This would help in biosequestration of $\mathrm{CO}_{2}$ and may also halt the unprecedented climate changes. Improved agricultural, horticultural, botanical, physiological and other photosynthetic techniques (using $\mathrm{C} 4$ crops) etc. may help in growing more biomass. Further research and development may be required to enhance manifold the availability of biomass so as to match the scales at which fossil fuels are being used in order to establish bioeconomy.

\section{Conclusions}

Extensive research was carried out during 1970-80 (as a consequence of earlier oil crisis) on the development of different biomass conversion technologies. This also included pilot plant development research on acid or enzymatic hydrolysis of biomass. Research and development may be extended further from there to make these processes cost effective.

\section{References}

Aden A, Ruth M, Ibsen K, Jechura J, Neeves K, Sheehan J and Wallace B (2002) Lignocellulosic biomass to ethanol process desigen and economics utilizing co-current dilute acid prehydrolysis and enzymatic hydrolysis for corn stover, National Renewable Energy Laboratory, Golden, $\mathrm{CO}$, USA

Ahmaruzzaman M and Sharma D K (2005) Non-isothermal kinetic studies on co-processing of vacuum residue, plastics, coal and petrocrops J Anal Appl Pyrol 73 263275

Ahmaruzzaman M and Sharma D K (2007a) Chemical reaction engineering studies on co-cracking of petroleum vacuum residue with coal, plastics and biomass (bagassse and petrocrop) Petrol Sci Technol 25 937-947

Ahmaruzzaman M and Sharma D K (2007b) Co-processing of petroleum vacuum residue with plastics, coal and biomass and its synergistic effects Energ Fuels 21 891-897

Angenent L T, Karim K, Al-Dahhan M H, Wrenn B A and Domiguez-Espinosa R (2004) Production of bioenergy and biochemicals from industrial and agricultural wastewater Trends Biotechnol 22 477-485

Balasundaram R, Gadgil K, Behera B K and Sharma D K (2007)
Current emphasis is on the production of bioethanol or biobutanol from the lignocellulosic wastes. However, considerable commercial activity has started on biodiesel production from nonedible oil seeds and this may be followed up to obtain the same from algae. There is a trend to exploit the use of grasses, agroresidues, microalgae, macroalgae, aquatic biomass, oilseeds or petrocrops, etc. for the production of value-added chemicals and pharmaceuticals. This would also help in the biosequestration of $\mathrm{CO}_{2}$. Productivity and availability of biomass may have to be increased manifold if biomass has to replace the role played by the fossil fuels today. This may also be required to establish bioeconomy in the future.

\section{Acknowledgement}

I would like to thank my research student, Ms. Akanksha Gupta, for her kind help in the formatting of this manuscript.

Photobiological production of hydrogen from Spirulina for fueling the fuel cells Energ Sources 29 761-767

Behera B K, Arora M and Sharma D K (1996) Scanning electron microscopic (SEM) studies on structural architecture of lignocellulosic materials of Calotropisprocera during its processing for saccharifications Biores Tech 58 241-245

Behera B K, Midha N, Arora M and Sharma D K (1995) Production of petroleum hydrocarbons, fermentable sugars and ethanol from Tabernaemontanadivaricata Energy Conv Manage 36 281-288

Biswas S, Mohanty P and Sharma D K (2013) Studies on synergism in the cracking and co-cracking of Jatropha oil, vacuum residue and high density polyethylene: kinetics analysis Fuel Process Technol 106 673-683

Biswas S and Sharma D K (2013) Studies on cracking of Jatropha oil J Anal Appl Pyrol 99 122-129

Biswas S and Sharma D K (2012) Synergistic co-processing/cocracking of Jatropha oil, petroleum vacuum residue and high density polyethylene J Renew Sustain Energ 4 1-11

Deeba F, Kumar V, Gautam K, Sexana R K and Sharma D K (2012) Jatropha curcas seed oil and deoiled seed hulls for the production of biodiesel and biogas Biomass Bioenerg 


\section{$4013-18$}

Demirbas A (2009b) Progress and recent trends in biodiesel fuels Energ Conv Manage 50 14-34

Demirbas A (2009a) Biofuels securing the planet's future energy needs Energ Conv Manage 50 2239-2249

Demirbas A (2011) Competitive liquid biofuels from biomass Appl Energ 88 17-28

Demirbas M F and Balat M (2006) Recent advances on the production and utilization trends of biofuels: A global perspective Energ Conv Manage 47 2371-2381

Discussion Meet on "Energy Biosciences Strategy for India" (2007) Department of Biotechnology, Govt. of India, New Delhi

Ganguly A, Chatterjee P K and Dey A (2012) Studies on ethanol production from water hyacinth-A review Renew Sustain Energ Rev 16 966-972

Gaurava D, Verma V, Sharma D K and Basu S (2010) Preliminary studies on development of direct alcohol alkaline fuel cell stack Fuel Cells 10 591-596

Gautam K, Pareek A and Sharma D K (2013) Biochemical composition of green alga Chlorella minutissima in mixotrophic cultures under the effect of different carbon sources J Biosci Bioeng 116 624-627

Goldstein I S (1981) Organic chemicals from biomass. CRC Press, Boca Raton, Fl., USA.

Gupta R B and Demirbas A (2010) Gasoline, diesel and ethanol biofuels from grasses and plants. Cambridge University Press (New York) pp 67-68

Joseph P V, Saxena D and Sharma D K (2007) Study of nonedible vegetable oils of Indian origin for lubricant application $J$ Synth Lubr 24 181-197

Joseph P V and Sharma D K (2010) Improvement of thermooxidative stability of nonedible oils of Indian origin for biodegradable lubricant application Lubr Sci 22 149161

Kalita D (2008) Hydrocarbon plant-new source of energy for future Renew Sustain Energ 12 455-471

Lee Y Y, Iyer P and Torget R W (1999) Dilute-acid hydrolysis of lignocellulosic biomass Adv Biochem Eng/Biotechnol 65 93-115

Ma F and Hanna M A (1999) Biodiesel production: a review Biores Technol 70 1-15

Maitan-Alfenas G P, Visser E M, and Guimarães V M (2015) Enzymatic hydrolysis of lignocellulosic biomass: converting food waste in valuable products Curr Opin Food Sci 1 44-49
Mohanty P, Pant K K and Sharma D K (2011) Liquid fuel production from syngas using bifunctional $\mathrm{CuO}-\mathrm{CoO}-$ $\mathrm{Cr}_{2} \mathrm{O}_{3}$ catalysts mixed with MFI zeolite Fuel Process Technol 92 600-608

Parthasarathy M R Ranganathan K R and Sharma D K (1979) 13-CNMR of flavonolignans from Hydnocarpuswightiana Phytochemistry 18 506-508

Ruan Z, Zanotti M, Zhong Y, Liao W, Ducey C and Liu Y (2013) Co-hydrolysis of lignocellulosic biomass for microbial lipid accumulation Biotechnol Bioeng 110 1039-1049

Shafiee S and Topal E (2009) When will fossil fuel reserves be diminished? Energ Pol 37 181-189

Shahid E M and Jamal Y (2011) Production of biodiesel: A technical review Renew Sustain Energ Rev 15 4732-4745

Sharma D K and Goldstein I S (1990) Reactivity towards phenolation of sulphuric acid lignins $J$ Wood Chem Tech 10 379-389

Sharma D K and Hall I H (1991) Hypolipidemic, antiinflammatory and antineoplastic and cytotoxicity of flavonolignans isolated from Hydnocarpuswightiana seeds J Nat Prod 54 1298-1302

Sharma D K and Mbise H A (1988) Biocrude and biomethane from Croton bonplandianum Resour Conserv Recycl 1111222

Sharma D K and Prasad R (1986) Oil and nonpolluting fuel from latex bearing plants Biomass 11 75-79

Sharma D K Ranganathan K R Bhushan B, Parthasarathy M R and Seshadari T R (1979) Flavonolignans from Hydnocarpuswightiana, Planta Medica J Med Chem 37 79-83

Sharma D K and Sahgal P N (1982) Production of furfural from agricultural wastes using presssurized water in a batch reactor J Chem Technol Biotech 32 666-668

Sharma D K (2005a) Pharmacological properties of flavonoids (including flavonolignans) - Integration of petrocrops with drug development from plants J Sci Ind Res 65 477-484

Sharma D K (2005b) Bioprospecting for drug research and functional foods for the prevention of diseases - Role of flavonoids in drug development $J$ Sci Ind Res 65 391-401

Sheehan J, Dunahay T, Benemann J and Roessler P (1998) A Look Back at the U.S. Department of Energy's Aquatic Species Program: Biodiesel from Algae by the National Renewable Energy Laboratory. Report NREL/TP-58024190, National Renewable Energy Laboratory, Golden, $\mathrm{CO}, \mathrm{USA}$

Singh A, Das K and Sharma D K (1984a) Production of reducing sugars from bagasse and rice husks Agricultural Wastes 9 $131-145$ 
Singh A, Das K and Sharma D K (1984b) Integrated process for production of furfural, xylose, glucose, and ethanol by two step acid hydrolysis Ind Eng Chem Prod Res Dev $\mathbf{2 3}$ 257-262

Stephans E, Ross I L, Mussugnug J H, Wagner L D, Borowitzka M A, Posten C, Kruse O and Hankamer B (2010) Future prospects of microalgal biofuel production systems Trends in Plant Sciences 15 554-564
Sun Y and Cheng J (2002) Hydrolysis of lignocellulosic materials for ethanol production Biores Technol 83 1-11

Wise D L (1983) Organic chemicals from biomass, The Benjamin Cumming Pub. Co., Inc., Menlo Park, CA, USA

Zhang, Yu H, Huang H and Liu Y (2007) Evaluation of biological pretreatment with white rot fungi for the enzymatic hydrolysis of bamboo culms International Biodeterioration and Biodegradation 60 159-164. 